\title{
Alternative splicing of human peroxisome proliferator-activated receptor delta (PPARdelta):effects on translation efficiency and trans-activation ability
} Kerstin Lundell*†, Petra Thulin ${ }^{\dagger}$, Anders Hamsten and Ewa Ehrenborg*

Address: The Atherosclerosis Research Unit, King Gustaf V Research Institute, Department of Medicine, Karolinska Institutet, Stockholm, Sweden Email: Kerstin Lundell* - Kerstin.Lundell@ki.se; Petra Thulin - Petra.Thulin@ki.se; Anders Hamsten - Anders.Hamsten@ki.se; Ewa Ehrenborg* - Ewa.Ehrenborg@ki.se

* Corresponding authors †Equal contributors

Published: 16 August 2007

BMC Molecular Biology 2007, 8:70 doi:10.1186/1471-2199-8-70
Received: 12 December 2006

Accepted: 16 August 2007

This article is available from: http://www.biomedcentral.com/I47I-2/99/8/70

(C) 2007 Lundell et al; licensee BioMed Central Ltd.

This is an Open Access article distributed under the terms of the Creative Commons Attribution License (http://creativecommons.org/licenses/by/2.0), which permits unrestricted use, distribution, and reproduction in any medium, provided the original work is properly cited.

\begin{abstract}
Background: Peroxisome proliferator-activated receptor delta (PPAR $\delta$ ) is a member of the nuclear receptor superfamily. Numerous studies have aimed at unravelling the physiological role of PPAR $\delta$ as a transcriptional regulator whereas the regulation of PPAR $\delta$ gene expression has been less studied.

Results: The principal transcription start site in the human PPAR $\delta$ gene identified here is positioned upstream of exon I, although four alternative 5 '-ends related to downstream exons were identified. The demonstration of multiple 5'-UTR splice variants of PPAR $\delta$ mRA, with an impact on translation efficiency, suggests a translational regulation of human PPAR $\delta$ expression. Five untranslated exons identified in this study contribute to the variability among the 5 '-UTRs of human PPAR $\delta$ mRNAs. Moreover, in vitro studies of a 3'-splice transcript encoding a truncated variant of PPAR (designated PPAR 2 2) show that this isoform constitutes a potential dominant negative form of the receptor.
\end{abstract}

Conclusion: We propose that alternative splicing of human PPAR $\delta$ constitutes an intrinsic role for the regulation of PPAR $\delta$ expression and thus activity, and highlight the significance of alternative splicing of this nuclear receptor in physiology and disease.

\section{Background}

Peroxisome proliferator-activated receptors (PPARs) are ligand-dependent transcription factors that activate target genes by binding to peroxisome proliferator response elements (PPREs) as heterodimers with the retinoid $\times$ receptor (RXR) (NR2B). Three PPAR isoforms encoded by different genes have been identified: $\alpha$ (PPAR $\alpha$ or NR1C1), $\delta / \beta$ (PPAR $\delta$ or NR1C2) and $\gamma$ (PPAR $\gamma$ or NR1C3). The functional specificity among members of the PPAR subfamily is achieved by isoform-specific tissue expression as well as ligand binding specificity [1-5]. Endogenous ligands that activate PPARs are polyunsaturated fatty acids or their derivatives [6-8]. Ligand activation of PPARs induces conformational changes that promote binding of co-activators that are essential for the trans-activating function whereas binding of nuclear corepressors is associated with transcriptional repression. PPAR $\delta$ is the only isoform that maintains repressor activity when bound to DNA. It has been reported that unligated PPAR $\delta$ can act as an intrinsic transcription repressor 
and inhibit the trans-activation activity of other PPARs [912 ]. Given that the PPAR $\delta$ gene is ubiquitously expressed this suggests an additional role for PPAR $\delta$ as a receptor whose relative level of expression can be used to repress the expression of PPRE target genes.

It was not until recently that the roles of PPAR $\delta$ were disclosed through utilization of specific ligands together with relevant cells and animal models. PPAR $\delta$ controls various physiological functions including lipid and glucose homeostasis, inflammation, cell proliferation and differentiation [13]. PPAR $\delta$-deficiency in mice negatively affects growth, adipose stores, epidermal cell proliferation, and myelinisation of corpus callosum $[14,15]$. Treatment of insulin-resistant obese rhesus monkeys with a PPAR $\delta$ specific ligand has been shown to promote cholesterol efflux, increase HDL levels and decrease LDL, triglyceride and insulin levels [16]. Further, PPAR $\delta$ is highly expressed in skeletal muscle, and treatment with PPAR $\delta$ specific ligands increases the proportion of oxidative slow-twitch myofibers and induces expression of genes involved in fatty acid utilization and oxidation as well as glucose uptake and metabolism [17-24].

Little is so far known considering how the expression of PPAR $\delta$ itself is regulated. Here we report on new 5'untranslated exons and multiple 5'-UTRs of PPAR $\delta$ mRNA transcripts, with an impact on the translation efficiency. In addition, we report on the expression of a 3'-splice variant of human PPAR $\delta$ (PPAR $\delta 2$ ), encoding a potential dominant negative regulator of gene expression. Since alternative splicing contributes to the regulation of gene expression and constitutes an important source of evolutionary diversity, we hypothesize that spliced mRNA isoforms of human PPAR $\delta$ play a role in controlling its function.

\section{Results}

Multiple untranslated exons and alternative transcription start sites

We have previously reported the human PPAR $\delta$ gene to encompass 9 exons of which exons 1-3, the 5'-end of exon 4 and the 3 '-end of exon 9 are untranslated [25]. An investigation was conducted aiming to identify possible alternative 5 '-ends in transcripts of PPAR $\delta$. Five new 5'untranslated exons in alternatively spliced transcripts of human PPAR $\delta$ mRNA were identified. The locations of these exons (designated exons $2 \mathrm{a}-2 \mathrm{e}$ ) in the gene sequence are outlined in Figure 1A. The newly identified exons were found at different time-points during the investigation and were subsequently re-annotated to indicate the relative position of each exon in the gene. Exons $2 a, 2 c$ and $2 e$ were originally found by 5 '-RACE using Marathon cDNAs from placenta, adipose tissue and pancreas. Combinations of these exons, including differently spliced forms of exon $2 \mathrm{a}$, were found to be spliced-in generating a variety of 5 '-UTRs, as displayed in Figure $1 \mathrm{~B}$. Exons $2 \mathrm{~b}$ and $2 \mathrm{~d}$ were subsequently found among sequenced PCR fragments generated using Marathon cDNAs and cell-derived cDNAs as templates and different combinations of 5'-untranslated exon-specific primers. The genomic locations and sequences of the splice junctions of spliced-in exons are summarized in Table 1. None of the 5'-UTRs found in this study contains any new inframe coding regions. Thus, the open reading frame (ORF) region encoded by exons 4 to 9 remains identical in all 5'-spliced transcripts.

The majority of the 5 '-splice PPAR $\delta$ transcripts contain exon 1 in the 5 '-end. However, alternative $5^{\prime}$-ends associated with exons $2 a, 2 c$ and $2 e$ were found, which is illustrated in Figure 1B, 5'-UTRs: $H-K$. Of these, the alternative 5 '-end containing full-length exon $2 \mathrm{c}$ was found only in pancreas (Figure 1B, 5'-UTR: I) whereas the others could be found in all three Marathon cDNAs. The genomic locations and sequences of the alternative 5 '-end exons are summarized in Table 2.

A bioinformatic approach to identify splice variants of human PPARS using the NCBI human Genome Browser and the human EST-search tool, indeed, showed the presence of exons $2 \mathrm{a}, 2 \mathrm{~b}, 2 \mathrm{c}$ and $2 \mathrm{~d}$ among 5 '-spliced transcripts of PPAR $\delta$, all with exons 1 and/or 2 upstream.

Table I: Sequences of splice junctions of newly identified spliced-in exons in the 5'-UTR of human PPAR $\delta$

\begin{tabular}{lllll}
\hline Spliced-in exon & Size (bp) & $\begin{array}{l}\text { Genomic position } \\
\text { downstream of exon 2 (bp) }\end{array}$ & 3'-splice acceptor & 5'-splice donor \\
\hline $2 \mathrm{a}$ & 641 & 1212 & ctgcagGGGTAG & TCGCAGgtagga \\
$2 \mathrm{~b}$ & 119 & 4427 & agatagCATCTC & CTACAGgtatgt \\
$2 \mathrm{c}$ & 122 & 5778 & tctcagGACCAG & TGTGAGgtaatg \\
$2 \mathrm{~d}$ & 315 & 36426 & atctagGAGGTG & TGGGAAgtgagg \\
$2 \mathrm{e}$ & 115 & 49826 & tttcagATTATC & TGTCCTgtgagt
\end{tabular}

The genomic positions of exons were deduced using the human PPAR $\delta$ RefSeq [GenBank: NM 006238]. Upper-case and lower-case letters indicate exon and intron sequences, respectively. The consensus splice donor-acceptor sequences are in bold letters. 


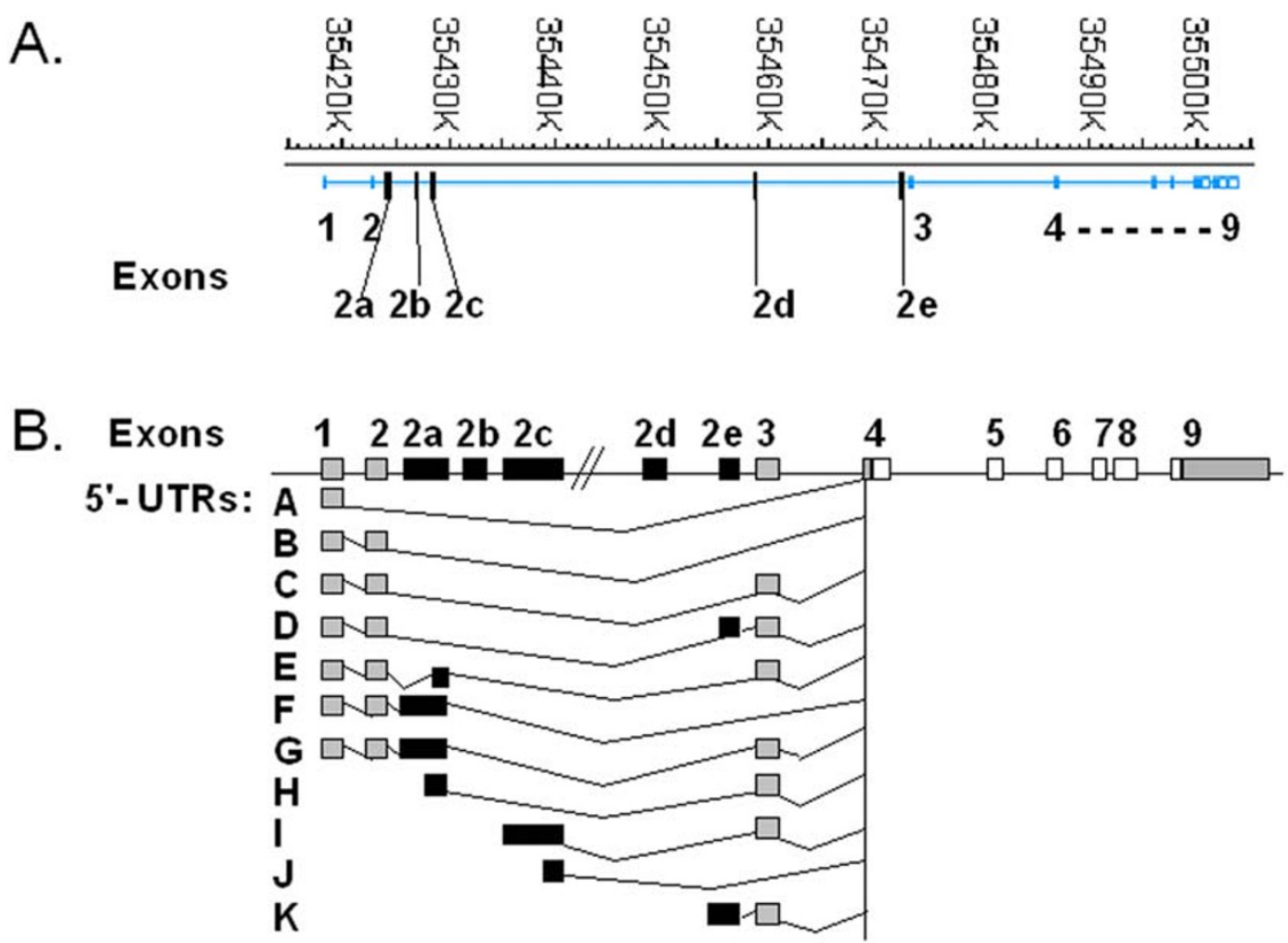

\section{Figure I}

Structure and chromosomal location of the human PPAR $\delta$ gene. A. A physical map of the $85 \mathrm{~kb}$ human $6 \mathrm{p} 21.3 \mathrm{I}$ region. The locations of exons are outlined with the previously known exons (denoted in upper row) and newly identified exons (denoted in lower row) indicated. The genomic positions of the new exons were deduced by comparing their sequences to that of the human PPAR $\delta$ gene [GenBank: NM 006238]. The sequences of splice junctions and alternative 5 '-ends related to these exons are outlined in Tables I and 2, respectively. B. A schematic representation of the PPAR $\delta$ gene showing coding exons (white boxes), previously reported untranslated exons or part of exons (grey boxes), and herein identified untranslated exons (black boxes). The analysed and discussed variety of splicing among untranslated exons and alternative 5 '-ends identified by Marathon 5'-RACE as described in "Methods" is shown below the gene (5'-UTRs: A-K).

Table 2: Sequences of identified alternative 5'-end exons in 5'-UTRs of human PPAR $\delta$ transcripts

\begin{tabular}{lllll}
\hline 5'-end exon & Size (bp) & $\begin{array}{l}\text { Genomic position } \\
\text { downstream of exon 2 (bp) }\end{array}$ & 5'-end & 5'-splice donor \\
\hline $2 a$ & 79 & 1774 & CCCAGTGGCAGC & TCGCAGgtagga \\
$2 c$ & 883 & 5017 & GCCAGTTCTTTT & TGTGAGgtaatg \\
$2 c$ & 318 & 5582 & CTTGATGCTGTT & TGTGAGgtaatg \\
$2 \mathrm{e}$ & 180 & 49761 & CAACCTCCCTGC & TGTCCTgtgagt \\
\hline
\end{tabular}

The genomic positions of exons were deduced using the human PPAR $\delta$ RefSeq [GenBank: NM 006238]. Upper-case and lower-case letters indicate exon and intron sequences, respectively. The consensus splice donor sequences are in bold letters. The relative positions of 5 '-ends in the gene are also illustrated in Figure IB, 5'-UTRs denoted H-K. 


\section{Expression of PPAR $\delta$ 5'-UTR isoforms in human cell lines and tissues}

Total RNA extracted from five different human cell lines was analysed by RT-PCR using different combinations of exon-specific PPAR $\delta$ primers. The presence of PPAR $\delta$ transcripts containing exons $2 \mathrm{a}, 2 \mathrm{c}$ and $2 e$ in all cell lines was confirmed by sequencing of PCR products (results not shown). Real-time PCR was subsequently conducted to estimate the relative amount of isoforms containing exons $2 a, 2 c$ and $2 e$ among transcripts of PPAR $\delta$ mRNAs. Samples of cDNA from human cell lines and from human skeletal muscle tissue as well as from adult and fetal heart tissues were subjected to TaqMan analysis using primers and probes specified in Table 3 . The analysis, illustrated in Figure 2, showed that in all cell lines and tissues studied the most common splice variant contained exons 2 and 4 joined together $(\mathrm{Ex} 2: 4)$ in the 5'-UTR. This variant was expressed in the same order of magnitude as the total amount of full length PPAR $\delta$ detected with primers targeting exons 8 and 9 (Ex8:9). Transcripts containing exon 2 joined to exon $2 \mathrm{a}(\mathrm{Ex} 2 \mathrm{2} 2 \mathrm{a})$ were expressed at a much lower level in all cell lines and tissues even though the level of expression varied and was higher in HeLa cells compared to skeletal muscle. The expression levels of transcripts containing isoforms joining exons $2 \mathrm{c}$ and 3 (Ex2c:3) as well as exons 2 and $2 e(E x 2: 2 e)$ were below the detection limit in all the cell lines and tissues studied.

\section{Analysis of promoter activities}

The majority of the 5 '-splice PPAR $\delta$ transcripts identified contain exon 1 in the 5 '-end, indicating that the previously identified promoter region upstream of exon 1 is the major region for transcriptional regulation of the human PPAR $\delta$ gene [25]. This was confirmed by transient transfection assays in both Huh7 and HeLa cells using a range of reporter gene constructs containing $2.6 \mathrm{~kb}$ to $48 \mathrm{bp}$ of the DNA sequence upstream of exon 1 (Figure 3 ). Maximum luciferase activity was obtained with the reporter construct containing $171 \mathrm{bp}$ of the promoter in both cell lines (Figure 3A). Shorter constructs showed declining activities with a major drop using the 48 bp construct. Likewise, longer constructs showed decreasing luciferase activities, indicating the presence of upstream transcriptional repressor element(s).

Reporter gene constructs encompassing approximately 1 $\mathrm{kb}$ and $250 \mathrm{bp}$, respectively, of the 5'-regions of each of the four putative transcription start sites (summarized in Table 2 and illustrated in Figure 1B, 5'-UTR: $H-K$ ) showed no or weak basal promoter activity in Huh7 and Hela cells compared with the identified promoter region upstream of exon 1 (Figure 3B). In silico analysis revealed a potential PPRE located -86 to -74 bp upstream of the identified alternative 5'-end within exon $2 \mathrm{a}$. However, the two reporter gene constructs ( $1 \mathrm{~kb}$ and $213 \mathrm{bp}$ ) containing this PPRE were neither affected by overexpression of PPAR $\delta$ nor PPAR $\alpha$ combined with isoform-specific ligands GW501516 [26] and fibrates, respectively (results not shown).

\section{Translation efficiency of PPAR $\delta$ ' - -splice variants}

The impact of different 5'-UTRs on the translation efficiency was analysed using coupled transcription/translation in a reticulocyte system (Promega). Plasmids harbouring seven different 5'-UTRs (denoted 5'-UTR: A-G in Figure $1 \mathrm{~B}$ ) placed in front of the PPAR $\delta$ coding region were analysed. The compiled results outlined in Figure 4 clearly show that transcripts with extended 5'-UTRs are less efficiently translated into protein. The [ $\left.{ }^{35} \mathrm{~S}\right]$ methionine labelled translation products were resolved by SDS-

Table 3: TaqMan primers and probes used in this study

\begin{tabular}{|c|c|c|}
\hline Name & Target & Sequence (5'-3') \\
\hline \multicolumn{3}{|l|}{ Forward primers } \\
\hline TQEx2Fw & exon 2 & 5'-GCTCACCAACAGATGAAGAC \\
\hline TQEx2cFw & exon $2 c$ & 5'-CCTCCTTGGAGACCAGCTA \\
\hline TQEx8Fw & exon 8 & 5'-GACCTGGCCCTATTCATTG \\
\hline \multicolumn{3}{|l|}{ Reverse primers } \\
\hline TQEx2aRev & exon $2 \mathrm{a}$ & 5'-GCATTGTTCAGACTCTTGGT \\
\hline TQEx2eRev & exon $2 e$ & 5'-CAGGGAAGGTTCAAGGTCAA \\
\hline TQEx3Rev & exon 3 & 5'-GTATCTGACCCTGCTTTCCA \\
\hline TQEx4Rev & exon 4 & 5'-TCTGAACGCAGATGGACCT \\
\hline TQEx9Rev & exon 9 & 5'-ACCCGTGGAACGTTCATGA \\
\hline \multicolumn{3}{|l|}{ Probes } \\
\hline $\mathrm{Ex} 2: 2 \mathrm{aPr}$ & Exons $2: 2 \mathrm{a}$ & 5'-FAM-ACСTCСTACCCCTCGTTGGTG-TAMRA \\
\hline $\mathrm{Ex} 2: 2 \mathrm{ePr}$ & Exons $2: 2 \mathrm{e}$ & 5'-FAM-CACCAACGAGATTATCTTGAAGAC-TAMRA \\
\hline $\mathrm{Ex} 2 \mathrm{c}: 3 \mathrm{Pr}$ & Exons $2 \mathrm{c}: 3$ & 5'-FAM-CATTCCAGACCCTCACATAAGGA-TAMRA \\
\hline $\mathrm{Ex} 2: 4 \mathrm{Pr}$ & Exons $2: 4$ & 5'-FAM-TCCCATCAGCCTCGTTGGTGC-TAMRA \\
\hline Ex8:9Pr & Exons 8:9 & 5'-FAM-CTGGCCGGTCTCCACACAGAA-TAMRA \\
\hline
\end{tabular}

The primers and probes are annotated according to the target exons and exon/exon junctions in the human PPAR $\delta$ gene, respectively. 

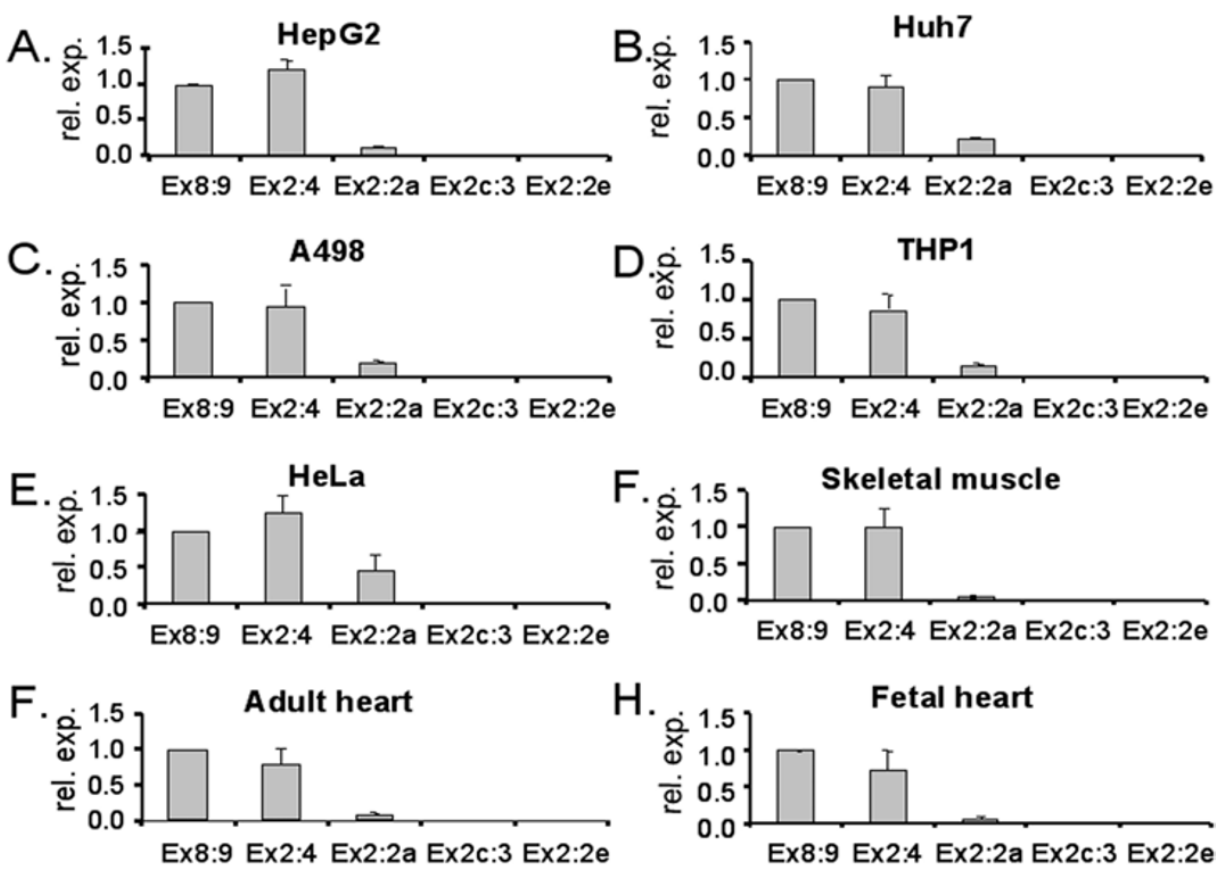

\section{Figure 2 \\ TaqMan analysis of splice products in human cell lines and tissues.}

Real-time PCR on cDNA from human cell lines (A-E) and human tissues (F-H) using primers and probes specified in Table 3 was performed as described in "Methods". The following combinations of primers and probes were used for each TaqMan assay; TQEx8Fw, TQEx9Rev and Ex8:9Pr (Ex8:9); TQEx2Fw, TQEx4Rev and Ex2:4Pr (Ex2:4); TQEx2Fw, TQEx2aRev and Ex2:2aPr (Ex2:2a); TQEx2cFw, TQEx3Rev and Ex2c:3Pr (Ex2c:3); TQEx2Fw, TQEx2eRev and Ex2:2ePr (Ex2:2e). The result of each assay was normalized to the result of the Ex8:9 assay using the comparative $C_{T}$ method and presented as the mean relative expression levels $( \pm \mathrm{SD})$.

PAGE and subjected to autoradiography (Figure 4A). Western blot analysis of the translated protein (Figure $4 B)$, using a PPAR $\delta$ specific antibody, showed immunoreactive proteins of compatible sizes (approximately 50 $\mathrm{kDa}$ ) and intensities as the autoradiogram (Figure 4A). The intensities of the $\left.{ }^{35} \mathrm{~S}\right]$ methionine and Western blot bands were quantified (Figure 4C). The alternatively spliced human PPAR $\delta$ 5'-UTRs differ in length and number of AUGs. All identified upstream AUGs are upstream open reading frames (uORFs) with an in-frame stop codon within the 5'-UTRs. The 5'-UTR sequences analysed harbour from 4 up to 14 upstream AUGs (Figure 4C). Strong inverse relationships were observed between the number of AUGs and the measure of quantified translation efficiency (\% Area) $(\mathrm{R}=0.97$ autoradiography; $\mathrm{R}=$ 0.90 Western blot) whereas that between the 5'-UTR length and \% Area was less pronounced $(\mathrm{R}=0.84$ autoradiography; $\mathrm{R}=0.71$ Western blot).

\section{Characterization of the truncated human PPAR $\delta$ isoform (PPAR $\delta$ 2)}

A 3 '-spliced isoform of human PPAR $\delta$, formed by exon 9 skipping, has been reported from human placenta cDNA clones [EMBL: BC007578 and BC002715, RefSeq GenBank: NM 177435]. Intron 8 is retained in the primary transcript and an in-frame stop codon (UGA) in the extended exon 8 encodes a protein lacking the C-terminal 82 amino acids of PPAR $\delta$, which constitutes the end of the ligand-binding domain. The presence of a PPAR $\delta 2$ transcript (identical to EMBL:BC007578 and BC002715) with a polyadenylation signal 583 nt downstream of the stop codon and a poly(A)tail attached was confirmed by 3'RACE using cDNA from placenta and adipose tissue (data not shown). Adaptor linked transcripts with a 3 '-end within intron 8 were also obtained from pancreas cDNA, however, poly(A)tail linked 3'-end transcripts could not be confirmed.

PCR amplification of placenta and adipose 5'-RACE products enriched in either full-length PPAR $\delta$ (PPAR $\delta 1$ ) or PPAR 2 , respectively, revealed some differences regarding 


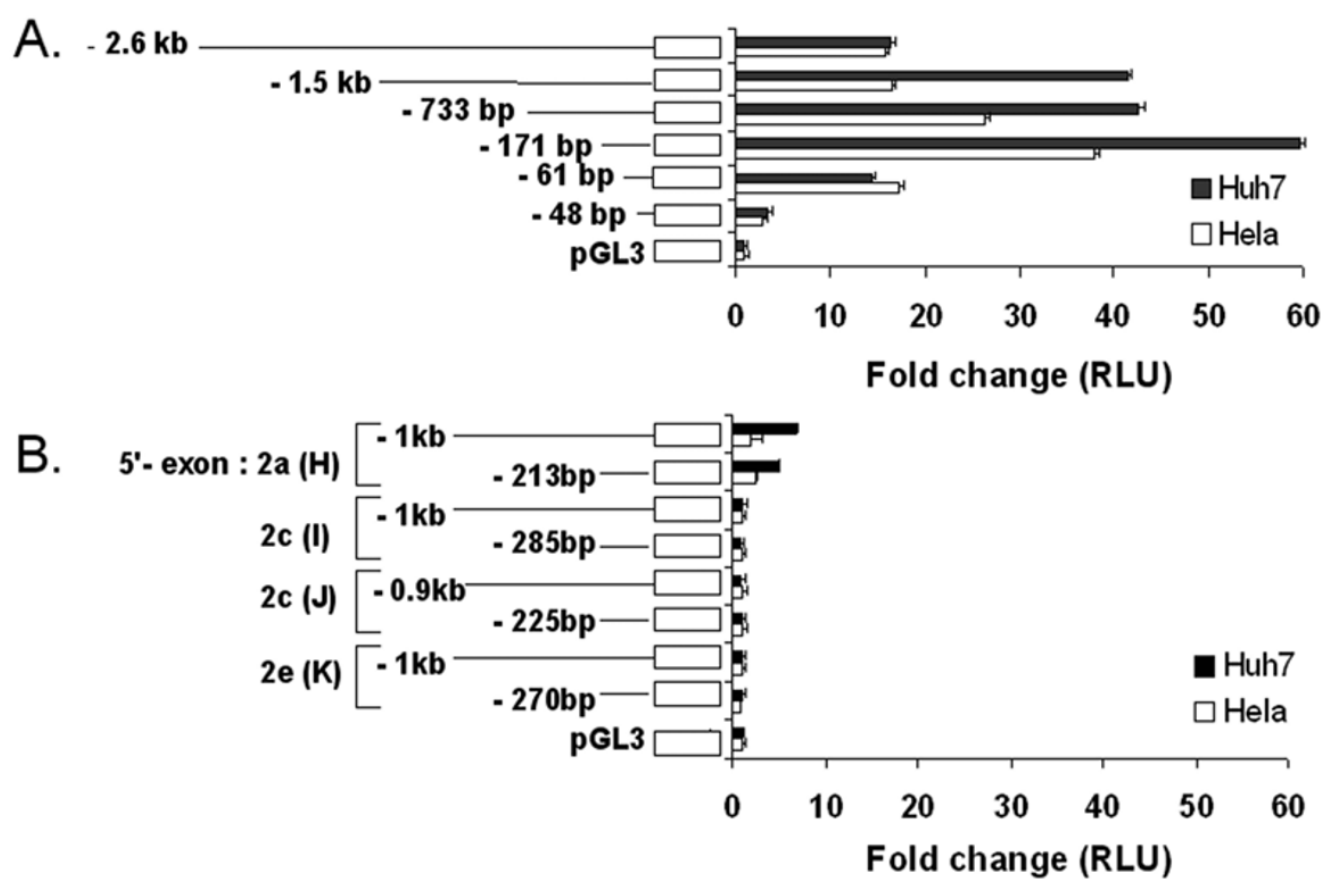

\section{Figure 3}

Reporter gene constructs and relative promoter activities. A schematic view of the different PPAR $\delta$ reporter gene constructs and the luciferase activities obtained after transient transfection in Huh7 (black bars) and HeLa cells (white bars), setting the value of the promoterless control plasmid to I. A. Luciferase assays on reporter gene constructs containing from 2.6 $\mathrm{kb}$ down to $48 \mathrm{bp}$ of the region upstream of exon I in the PPAR $\delta$ gene compared to empty pGL3 vector. $B$. Luciferase assay on reporter gene constructs containing approximately I kb and $250 \mathrm{bp}$ of the upstream regions of four identified alternative 5'ends summarized in Table 2 and illustrated in Figure IB (5'-UTRs: H-K), compared to empty pGL3 vector.

the variety of untranslated exons among 5'-UTRs, as illustrated in Figure 5. A sequence within the coding region (exons 4 to 8 ) as well as sequences encompassing exons 1 to 2 and exons 2 to 4 could be amplified using all 5'-RACE products (Figure $5 \mathrm{~A}-\mathrm{C}$ ). Transcripts containing exons 3 , $2 \mathrm{a}, 2 \mathrm{c}$, and $2 \mathrm{e}$ (Figure 5D-G) appeared, on the other hand, to be absent in samples enriched in PPAR $\delta 2$.

To analyse the trans-activating ability of PPAR $\delta 2$, the pFABPLUC reporter activity was investigated during overexpression of PPAR $\delta 2$ in the absence or presence of the expression vector for full-length PPAR $\delta$ (PPAR $\delta 1)$ and the PPAR $\delta$ specific ligand GW501516 [26]. Co-transfection of pFABPLuc and the expression vector for PPAR $\delta 1$ in HeLa cells and treatment with GW501516 (10 nM and $100 \mathrm{nM}$ ) increased the trans-activation ability in a dose-dependent manner (Figure 6A). PPAR 82 , on the other hand, had no trans-activation ability in the presence of GW501516 (Figure 6A) but rather repressed the ligand-induced activation of pFABPLuc reporter by PPAR $\delta 1$ (Figure 6B). The expression of PPAR $\delta 1$ and PPAR $\delta 2$, respectively, in transfected HeLa cells was confirmed by Western blot analysis showing immunoreactive bands of expected sizes (approxi- mately $50 \mathrm{kDa}$ and $40 \mathrm{kDa}$ ) (Figure 6C). Gel retardation analysis showed that full-length PPAR $\delta 1$ binds to the functional PPRE of the rat acyl-CoA oxidase gene in the presence of RXR whereas PPAR $\delta 2$ does not bind (Figure 7).

\section{Comparative genomics}

The human and mouse PPAR $\delta$ RefSeqs were compared and revealed an overall conserved pattern of exons and introns. Two 5'-untranslated exons are conserved between the human and mouse genes as illustrated in Figure 8 . The mouse exon 1A, previously reported to be positioned upstream of exon 1B [27], was found to be located downstream of exon 2 in the mouse RefSeq. The two genes harbour six and three, respectively, species-specific 5'untranslated exons. All these exons, except for mouse exon 1C, are located between exon 2 and the first coding exon, a region with no apparent sequence conservation between species. Comparative analysis using the ECR Browser tool [28], on the other hand, revealed regions of conservation relative to the human PPAR $\delta$ gene in the chimpanzee, rhesus macaque and dog orthologous genes as depicted in Figure 9. The genomic positions of the 


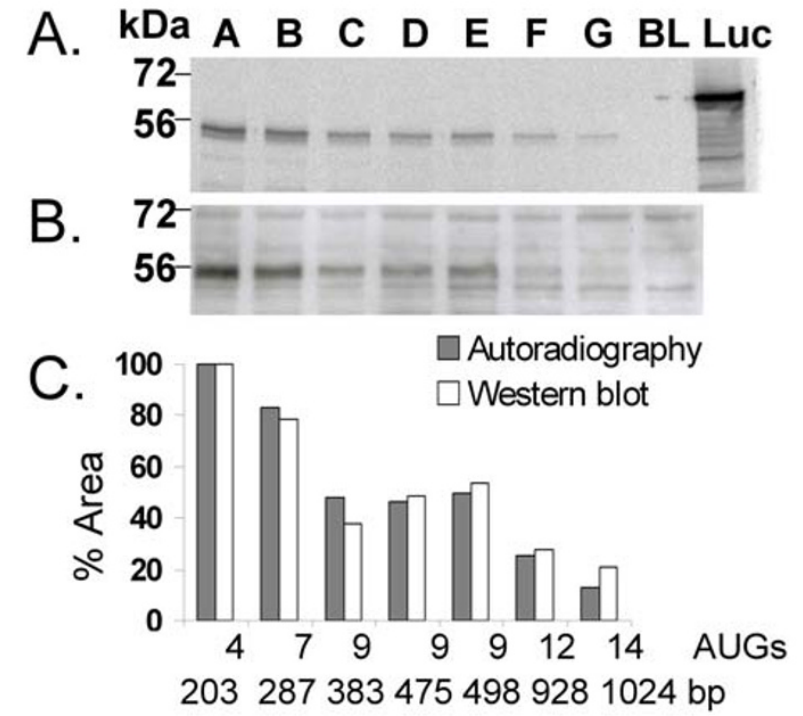

Figure 4

The compiled results of the in vitro coupled transcription/translation analysis.

A. Denaturing gel analysis of [ $\left.{ }^{35} \mathrm{~S}\right]$ methionine labelled translation products visualized by autoradiography. Samples A-G correspond to the in vitro-translated products obtained using Quick CoupledTranscription/Translation System (Promega) as described in "Methods" with plasmid DNA templates containing human PPAR $\delta$ with the 5 '-UTRs denoted A-G in Figure IB. The composition of untranslated exons in the 5'UTRs are: (A) Exon I, (B) Exons I+2, (C) Exons I+2+3, (D) Exons I+2+2e+3, (E) Exons I+2+spliced $2 \mathrm{a}(90 \mathrm{bp})+3$, (F) Exons $\mathrm{I}+2+2 \mathrm{a},(\mathrm{G})$ Exons $\mathrm{I}+2+2 \mathrm{a}+3$. $\mathrm{BL}$ is a negative control sample without template and Luc is a positive luciferase control sample.

$B$. Western blot analysis of the products of the translation reactions probed with the polyclonal PPAR $\delta$ specific antibody IMG-3297. The sizes of standard molecule markers are given on the left side $(A$ and $B)$.

$C$. Quantification of the [ $\left.{ }^{35} \mathrm{~S}\right]$ methionine labelled band intensities was performed on the autoradiographic (grey bars) and Western blot (white bars) bands using the NIH ImageJ software. The relative intensities of signals (\% Area) were calculated setting the signal of construct $A$ to $100 \%$. The number of upstream AUGs and the total length of each 5'-UTR is given below each bar of calculated signal.

human PPAR $\delta$ exons $2 \mathrm{a}$ and $2 \mathrm{e}$ within evolutionary conserved regions and of exons $2 b, 2 c$ and $2 d$ within repetitive regions are indicated in Figure 9. Repetitive regions are masked prior to comparative analysis of conserved region in the ECR Browser alignment and thus excluded from comparison. Using ClustalW alignment the masked regions harbouring the sequences of the orthologous exons $2 \mathrm{~b}$ and $2 \mathrm{c}$ in chimpanzee, macaque and dog revealed an overall sequence identity of $98 \%, 59 \%$ and
$15 \%$, respectively, compared with the human PPAR $\delta$ counterpart, as indicated in Figure 9. The masked region containing exon $2 \mathrm{~d}$, on the other hand, showed no sequence similarity between species. Identity scores and lengths of matching sequences to the human exons identified in the PPAR $\delta$ gene of chimpanzee, macaque and dog are given in Table 4.

The overall sequence conservation between human and chimpanzee PPAR $\delta$ genes is pronounced. Moreover, the NCBI HomoloGene database displays two isoforms of chimpanzee PPAR $\delta$ mRNA, denoted isoforms 3 [GenBank: XM_001172224] and 4 [GenBank: XM_001172238], which harbour spliced forms of exon $2 a$.

The major process whereby new exons evolve is considered to be exonization of intronic sequences [29,30]. The primate specific Alu-elements can be exonized through a small number of mutations. Using the RepeatMasker to analyse the human PPAR $\delta$ gene, exon $2 \mathrm{~b}$ was found to fulfil the criteria of being an Alu-derived exon [31,32]. Similar antisense Alu-elements are present in the corresponding region of the chimpanzee and macaque genes, both with mutations to enable exonization of orthologous exon 2b. A second exon-associated Alu-element is present in the $5^{\prime}$-end of exon $2 \mathrm{c}$, close to the alternative 5 '-end identified in pancreas. This Alu-element is conserved in the chimpanzee PPAR $\delta$ gene. Exon $2 \mathrm{~d}$ is

Table 4: Sequence identity scores of human PPAR $\delta$ exons in comparable regions of orthologous genes

\begin{tabular}{lccc}
\hline Human (bp) & $\begin{array}{c}\text { Chimpanz } \\
\text { ee Score } \\
\text { (bp) }\end{array}$ & $\begin{array}{c}\text { Macaque } \\
\text { Score (bp) }\end{array}$ & $\begin{array}{c}\text { Dog Score } \\
\text { (bp) }\end{array}$ \\
\hline Exon 2 (84) & $98(84)$ & $97(84)$ & $85(84)$ \\
Exon 2a (64I) & $98(641)$ & $95(639)$ & $82(622) \dagger$ \\
Exon 2b (II) & $99(119)$ & $74(122)$ & - \\
Exon 2c (883) & $98(852)$ & $-*$ & $77(507) \dagger$ \\
Exon 2d (312) & - & - & - \\
Exon 2e (II5) & $99(129)$ & $89(66) \dagger$ & $58(141) \ddagger$ \\
Exon 3 (96) & $99(96)$ & $95(84) \dagger$ & $39(103) \ddagger$ \\
Coding exons & 99 & 95 & 91 \\
\hline
\end{tabular}

Identity scores were calculated by ClustalW alignments and include scores for the novel human PPAR $\delta$ exons and human exon 2 , exon 3 and coding exons (I326 bp) for comparison. Exon I was not included since complete sequence information for this exon is not available for all species. Scores given in italic numbers indicate a sequence without conserved splice junctions.

* Sequence comparison precluded by unsequenced gaps in the macaque PPAR $\delta$ gene

†A full-length exon is not conserved. Identity scores are given for a sequence homologous to the 3'-region of the comparable human exon

$\ddagger$ An orthologous exon was not identified. Identity scores are given for a sequence with the highest homology scores within the genomic region comparable to the location of the human exon 


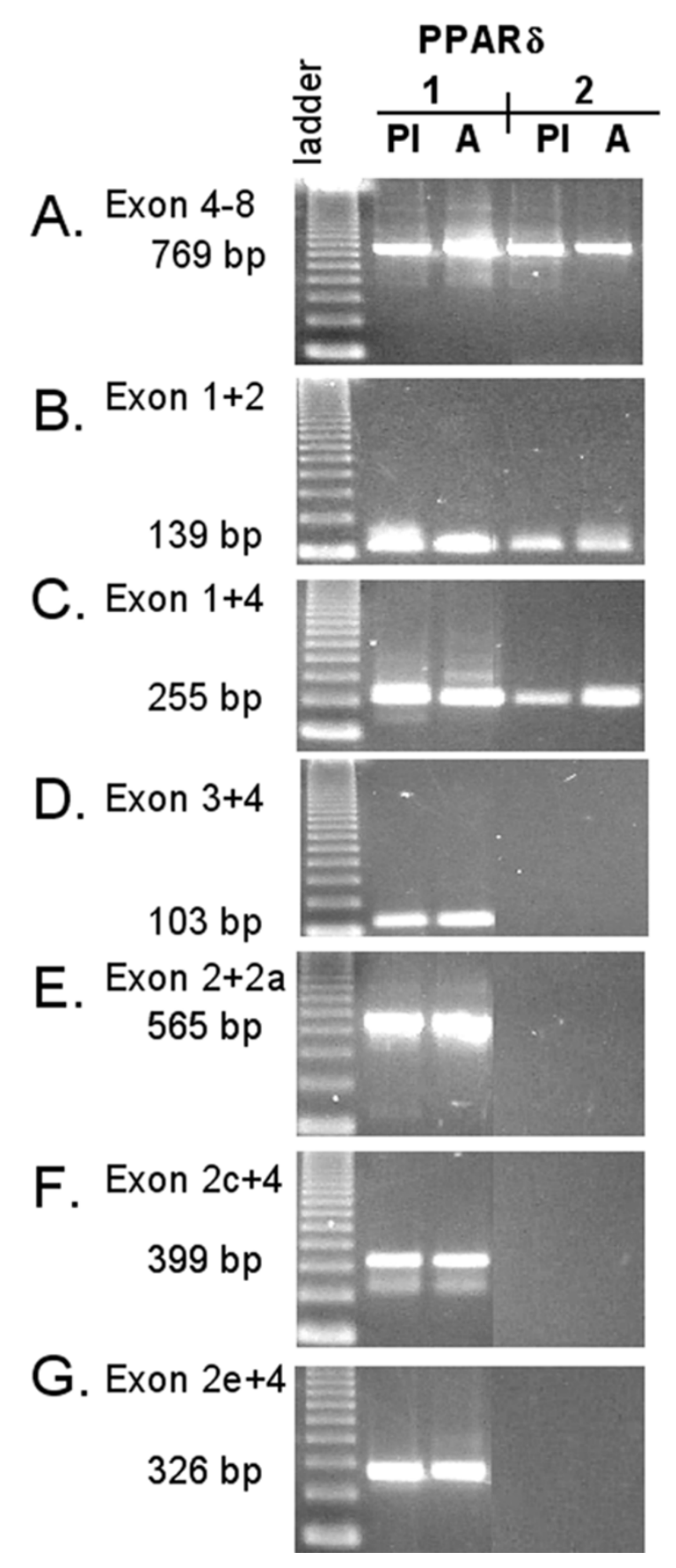

\section{Figure 5}

PPAR $\delta$ isoform-specific variability among 5'-UTRs. 5'-RACE products enriched in either full-length PPAR $\delta$ (PPAR $\delta I)$ or PPAR $\delta 2$ obtained using cDNA from placenta (PI) and adipose tissue (A) according to "Methods" were used as templates for $P C R$ reactions with untranslated exon/exon primer pairs, and with primers that amplify over exons in the coding region as control. A. Exon 4 to 8 (769 bp) amplified using Ex4Fw and Ex8Rev; B. Exon I + 2 (I 39 bp) amplified using ExI:2Fw and Ex2Rev; C. Exon I + 4 (255 bp) amplified using ExI:2Fw and Ex4:2Rev; D, Exon $3+4$ (I03 bp) amplified using Ex3Fw and Ex4:2Rev; E, Exon $2+2 \mathrm{a}(565 \mathrm{bp})$ amplified using Ex2Fw and Ex2a:IRev;F, Exon 2c + 4 (399 bp) amplified using Ex2cFw and Ex4:IRev;G, Exon $2 e+4$ (326 bp) amplified using Ex2eFw and Ex4:2Rev. The sizes of the major bands obtained are indicated and the identities of the products were confirmed by sequencing. 
A.

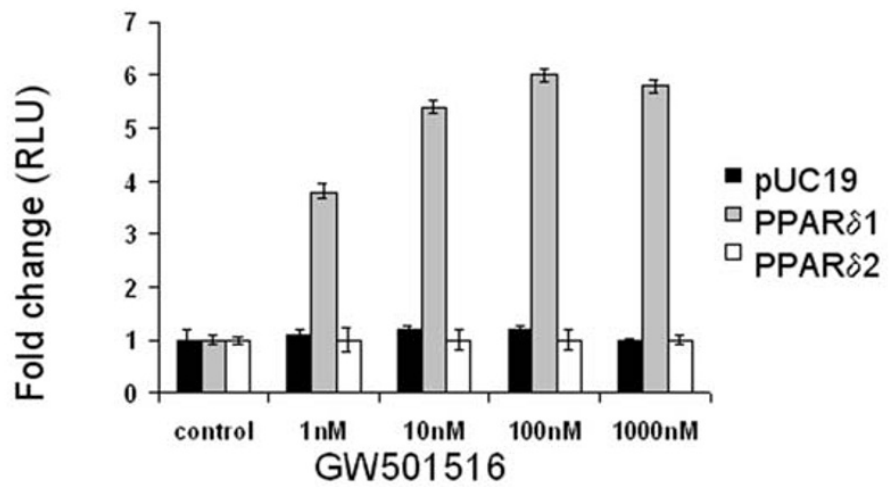

B.

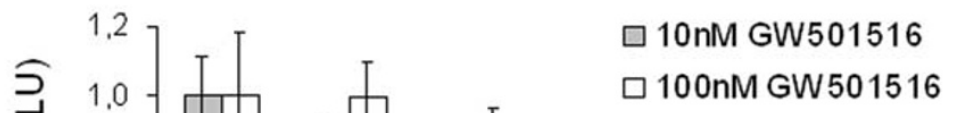

C.

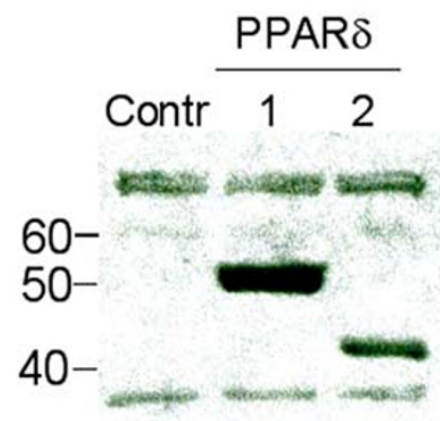

\section{Figure 6}

Trans-activation ability of PPAR $\delta 2$ investigated by transient transfection of HeLa cells. A. Co-transfection of pFABPLuc reporter construct (200 ng) with expression vector for either PPAR $\delta$ I (I $00 \mathrm{ng}$ ), PPAR $\delta 2$ (I00 ng) or irrelevant plasmid DNA pUCI9 (I00 ng), untreated (control) or treated with I nM, I0 nM or I00 nM of the PPAR $\delta$ specific ligand GW50I5I6. B. Co-transfection of pFABLuc reporter construct $(200 \mathrm{ng})$ with constant amount of expression vector for PPAR $\delta$ I (50 $\mathrm{ng})$ and increasing concentrations of the expression vector for PPAR $\delta 2$ (50 to $200 \mathrm{ng}$ ) and treatment with $10 \mathrm{nM}$ or $100 \mathrm{nM}$ GW501516. Transfection of the pFABLuc vector alone was used as a control. Plasmid DNA pUCI9 was added to ensure equal amount of DNA in all transfections. Plasmid PSV- $\beta$-galactosidase control vector (Promega) (260 ng) was co-transfected in all experiments for normalization of the transfection efficiency. The data presented are the mean $( \pm$ SD) luciferase/ $\beta$-galactosidase ratios of three independent transfections determined in quadruplicates. The activities are expressed as relative values setting the value of untreated control to I $(A)$ or the value obtained without PPAR $\delta 2$ expression plasmid to I (B). C. Western blot analysis with nuclear extracts prepared from untransfected HeLa cells (Contr) and HeLa cells transfected with the expression vectors encoding PPAR $\delta$ I or PPAR $\delta 2$, respectively, using a PPAR $\delta$ antibody raised against the $\mathrm{N}$-terminal region of the nuclear receptor (sc-7197, Santa Cruz Biotechnology). The sizes of standard molecule markers are given on the left side. 


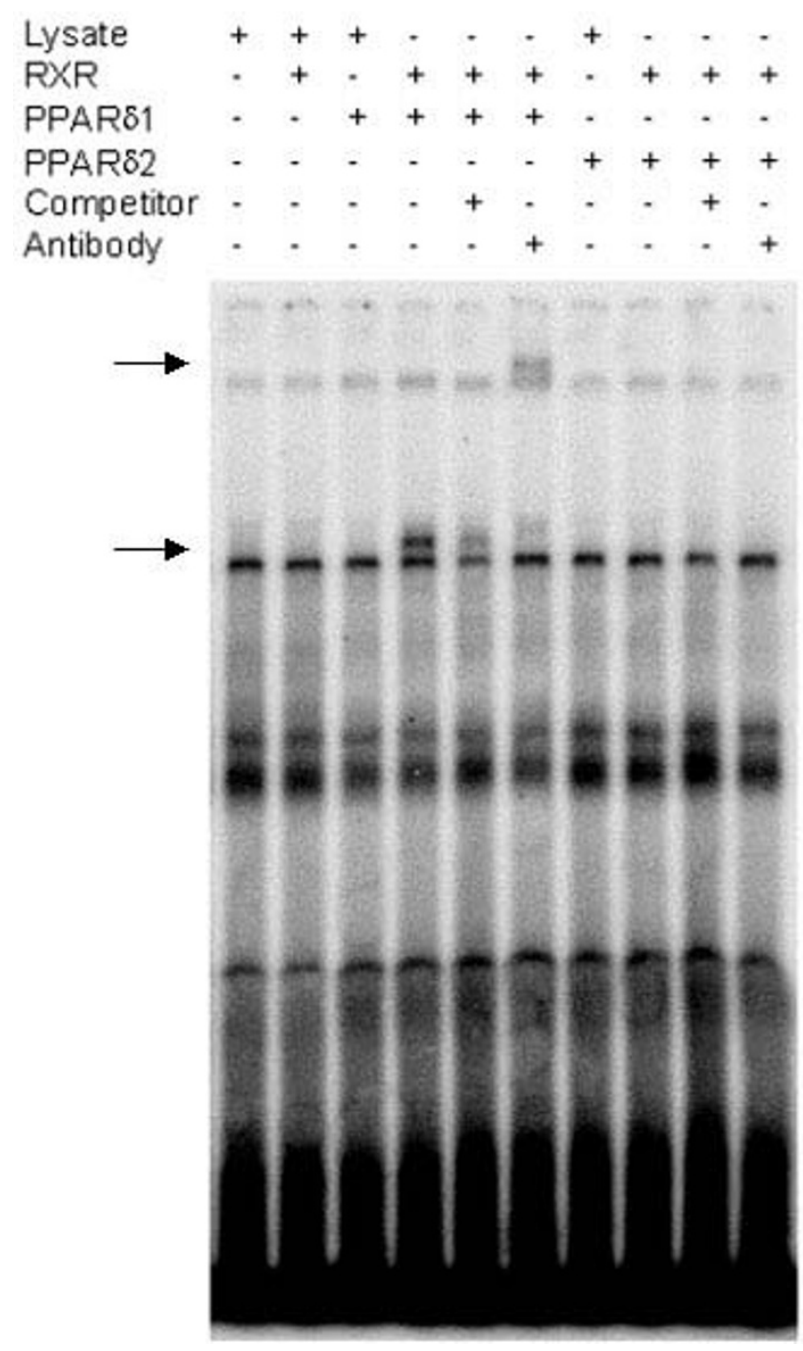

Figure 7

EMSA to assess the binding properties of PPAR $\delta$ isoform $I$ and 2 to ACO-PPRE. Gel retardation assay was performed with end-labelled ACO-PPRE in the presence $(+)$ or absence (-) of in vitro transcribed/translated human PPAR $\delta$ I, PPAR $\delta 2, R X R \alpha$ or mock lysate as described in "Methods". Unlabelled ACO-PPRE was added at 100 -fold molar excess for competition. Supershift experiments were carried out using a PPAR $\delta$ antibody directed against the $\mathrm{N}$ terminal region of human PPAR $\delta$. Arrows indicate the positions of the shifted and the supershifted bands. None of the receptors (PPAR $\delta I$, PPAR $\delta 2$ or $R X R \alpha$ ) alone could be supershifted in the presence of the PPAR $\delta$ antibody (data not shown).

located within a SVA element (SVA_D), named after its main components; short interspread nuclear element (SINE), variable number of tandem repeats (VNTR) and Alu [33]. In general this subfamily of SVA elements is believed to predate the divergence of human and chim- panzee lineage but is not present in the chimpanzee $\operatorname{PPAR} \delta$ gene. Exon $2 \mathrm{~d}$ is thus truly a human specific exon.

Homologues to the human PPAR $\delta 2$ isoform are presented in the NCBI GenBank as isoform models for both chimpanzee and macaque [GenBank: XM 001172194 and

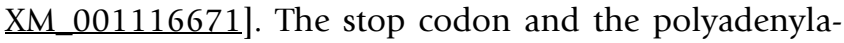
tion signal in intron 8 are fully conserved in the PPAR $\delta$ genes of these primates. The potential 3'-UTRs of chimpanzee and macaque PPAR $\delta 2$ show 99\% and 94\% overall sequence identity to the human counterpart, respectively. This pronounced sequence conservation indicates that PPAR $\delta 2$ could be a primate specific isoform.

\section{Discussion}

A diversity of 5'-UTRs derived from alternative splicing was identified among human PPAR $\delta$ mRNAs in this study. The majority of 5'-UTRs have exon 1 in the 5'-end, and reporter gene analysis using Huh7 and HeLa cells suggests that the main promoter of human PPAR $\delta$ is positioned upstream of exon 1. As previously reported [25], this promoter does not have a consensus TATA-box but is rich in potential $\mathrm{Sp}-1$ binding elements, a typical feature for house-keeping genes. This region contains evolutionary conserved areas between the human and mouse PPAR $\delta$ genes. Alternative promoters could, however, be present in the human PPAR $\delta$ gene, as is the case for the mouse orthologous gene [27]. Contrary to this assumption, reporter gene analysis using Huh7 and HeLa cells showed a low promoter activity related to only one of the four alternative promoter regions tested. Analysis of other cell types could, however, provide a different result. The identified alternative 5'-ends might represent tissue- or developmental-specific alternative transcription starts sites or be the products of as yet unknown post-transcriptional processing. A tissue-specific alternative transcription start site could apply to one alternative 5 '-end, which was detected only in cDNA from pancreas.

Several levels of regulation of PPAR activity have been reported such as phosphorylation by kinases that affects the transactivation potential and ubiquitin-proteosome degradation, a mechanism to arrest transcriptional activation [26,34-38]. The post-transcriptional regulation by 5'splicing suggested here for human PPAR $\delta$ and previously reported for the mouse orthologous gene [27] could represent one additional level of regulation. At least eight exons can be included in the 5'-UTR region of human PPAR $\delta$ transcripts by alternative splicing; the previously identified exons 1, 2 and 3 [25] and the five exons (2a-2e) identified in this study. The untranslated human PPAR $\delta$ exons are not mutually exclusive but rather appear to be spliced-in forming a diversity of 5'-UTRs containing any combination of exons. In addition to the splice variants discussed and depicted in Figure 1B, ten more combina- 


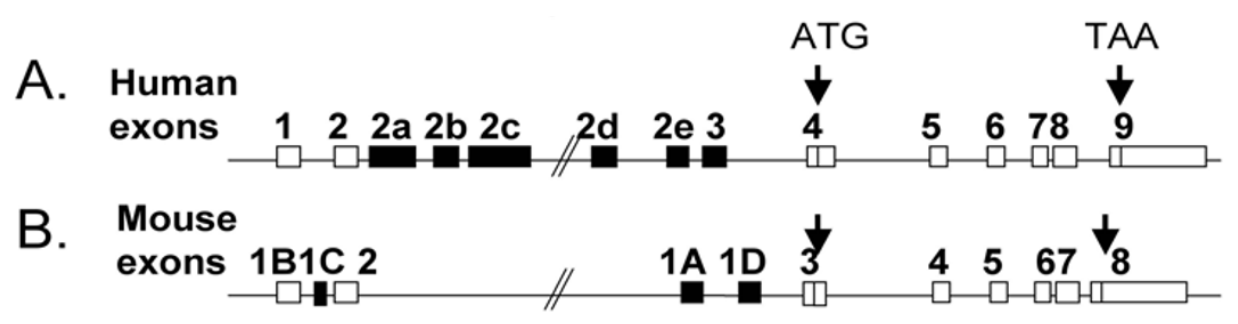

\section{Figure 8}

Comparing the organization of the human and mouse PPAR $\delta$ genes. A. The human PPAR $\delta$ gene (85 kb) located on chr6, B. The mouse ortologue gene $(70 \mathrm{~kb})$ located on chr I7. The overall difference in length can be accounted for by the 63 $\mathrm{kb}$ versus $50 \mathrm{~kb}$ separating exon 2 and the first coding exon (4 or 3 ) in human and mouse genes, respectively. The relative positions of exons along the genes are given, specifying exons that are conserved between species (white boxes) and species-specific exons (black boxes). Arrows indicate the position of the initiation codon ATG and the stop codon TAA, respectively, with the intervening coding exons.

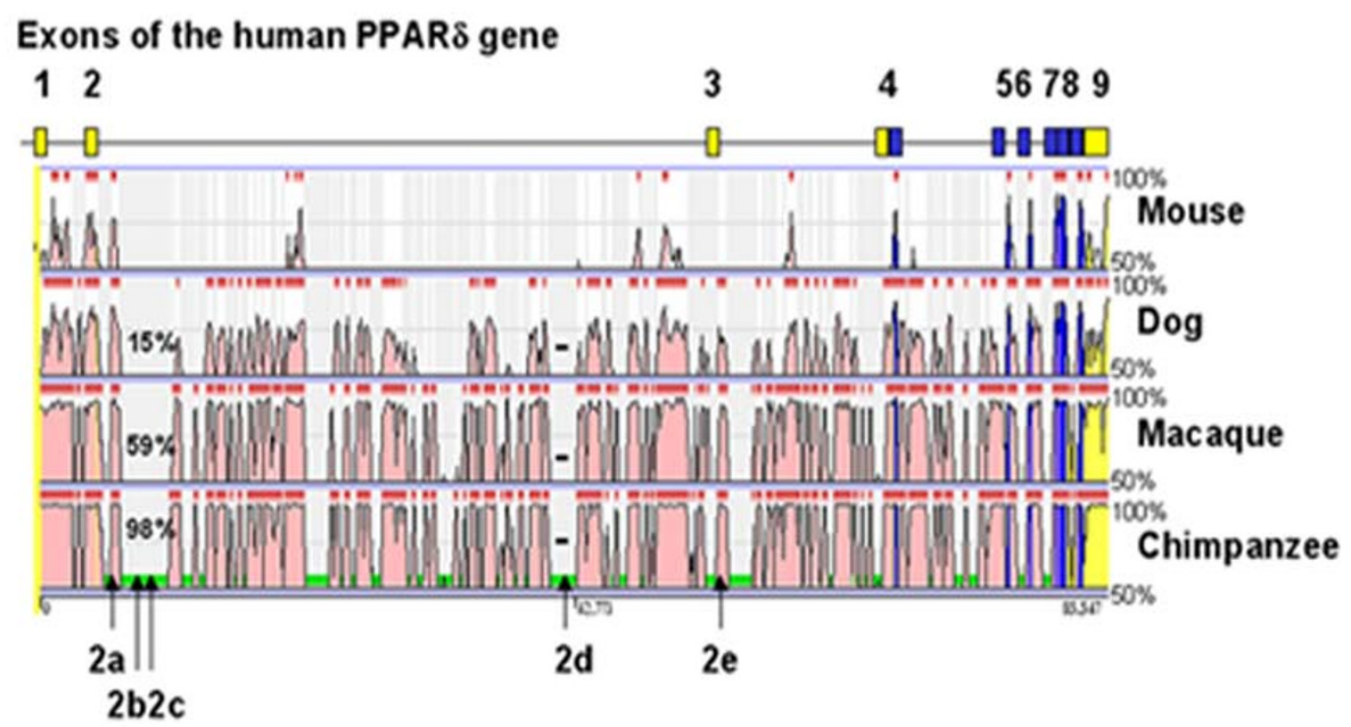

\section{Figure 9}

Conservation profiles of the PPAR $\delta$ gene using the ECR Browser tool. The conservation profiles (percent identity cut-off of $50 \%$ to $100 \%$ ) of the human PPAR $\delta$ gene in comparison with the mouse (Mus musculus; chr I7), dog (Canis familiaris; chrl2), macaque (Macaca mulatta; chr4) and chimpanzee (Pan troglodytes; chr6) orthologous genes are shown. Conserved sequences are defined as coding exons (blue), untranslated exons (yellow) and introns (pink). The locations of the novel untranslated human exons $(2 a-2 e)$ in the PPAR $\delta$ gene are indicated by arrows. The percent identity of the masked (unaligned) sequence harbouring exons $2 b$ and $2 c$ obtained by ClustalW alignment is indicated in the defined area, likewise the lack of identity over the masked region containing exon $2 d$ is indicated by horizontal lines. A schematic view showing the locations of previously identified exons in human PPAR $\delta$ gene are aligned above the conservation profile for orientation. 
tions involving the herein identified untranslated exons and the previously reported untranslated exons 1, 2 and 3 have been observed, either by sequencing of PCR products in this study or in data from the human EST-data base. The newly identified exons are positioned within the 63 $\mathrm{kb}$ long sequence separating exon 2 and the first coding exon. Interestingly, all PPAR isoforms share a similar gene organization with long introns separating untranslated exons from coding exons. The presence of several new splice variants affecting the 5'-UTR region of PPAR $\gamma$ was recently reported [39]. Likewise multiple isoforms of human PPAR $\alpha$ with variable 5'-UTRs are presented in the NCBI HomoloGene database.

Different combinations of 5'-untranslated human PPAR $\delta$ exons form 5'-UTRs of various length and numbers of upstream AUGs. The originally postulated scanning mechanism for initiation of translation predicts that translation should be initiated at the first AUG codon closest to the 5'-end of the mRNA [40]. However, upstream AUGs that are followed by a run of codons that ends in a termination codon within the 5'-UTR, so called upstream open reading frames (uORFs), play a role in translational regulation $[41,42]$. The strong correlation between the number of upstream AUGs and the observed translation efficiency indicates that the regulation of the yield of PPAR $\delta$ per unit mRNA involves uORFs. An influence on translation by GC rich regions with a potential to form stable secondary structures in the more extended 5'UTRs cannot be ruled out. The possibility of an initiation of translation by internal ribosomal entry sites (IRES) that circumvents upstream AUG codons and secondary structures is intriguing. The presence of IRES in the 5'-UTRs of many growth regulatory genes is believed to provide a means for the tuning of their translation in time and space and in response to relevant stimuli [43].

Our results and available human EST data suggest a ubiquitous occurrence of the newly identified exons in human PPAR $\delta$ mRNAs. Quantification using real-time PCR, however, showed that the overall preferred 5'-UTR is short, containing only exons 1 and 2, thus representing the majority of the human PPAR $\delta$ transcripts. Besides this, only mRNA isoforms containing exon $2 \mathrm{a}$ are present in measurable amounts. Considering that the presence of full-length exon $2 \mathrm{a}$ contributes substantially to the reduced translation efficiency, it is tempting to speculate that occurrence of exon 2a might be of importance for the functional roles of human PPAR $\delta$.

The generation rate of new exons has been calculated to approximately $2.71 \times 10^{-3}$ per gene per million years [44]. Most new exons are considered to originate from exonization of intronic sequences and appear in minor splice forms, which is in agreement with the finding in this study. An important question that remains to be answered is whether the low-abundant splice variants containing the newly identified exons represent biologically significant and functional isoforms. Comparative genomics was used as a guide to identify conserved sequence element, considering that functional regions generally are under strong selection pressure to stay unchanged. The previously identified untranslated exons 1 and 2 are highly conserved between species whereas the newly identified human PPAR $\delta$ exons are either human- or primate-specific exons. Exon $2 \mathrm{~d}$ was identified as a human-specific exon. All other novel exons are highly conserved in chimpanzee whereas only two exons (exons $2 \mathrm{a}$ and $2 \mathrm{~b}$ ) show the same high conservation in macaque. Likewise, all features related to the four alternative $5^{\prime}$-ends identified for the human PPAR $\delta$ are fully conserved in chimpanzee whereas only one, the $5^{\prime}$-end related to exon $2 \mathrm{a}$, is preserved in the macaque. At present, however, there is no available EST data to predict alternative splicing or promoter usage of PPARס in chimpanzee or macaque.

The sequence of exon 2a appears to be the most conserved of the five new human PPAR $\delta$ exons. All features related to this exon, including internal splice junctions and a putative 5'-end, are fully conserved in both the chimpanzee and macaque genes. Alternative splicing involving a homologous exon $2 \mathrm{a}$ in chimpanzee is suggested by available PPAR $\delta$ isoforms for this species. The overall conservation of the exon 2a sequence is surprisingly high in the dog gene. However, it is highly unlikely that an orthologous exon is spliced in this species.

Taken together, it is likely that transcripts with a short 5'UTR provide a constant basal level of PPAR $\delta$ synthesis. Transcripts with extended 5'-UTRs, such as the mRNA isoforms containing full-length exon $2 a$, with multiple AUG codons and potential secondary structures, could provide a spatio-temporal regulation of protein expression during for example growth, development, differentiation and stress. It has been reported that dysregulation of key proteins regulating growth and differentiation via modulation of 5'-UTR activity plays a role in the development or progression of various forms of cancer [43]. Whether mechanisms related to alternative splicing of PPAR $\delta$ could contribute to the conflicting findings regarding the role of this nuclear factor in cancer development remains to be investigated [13]. Likewise, the role of alternative promoters in the regulation of human PPAR $\delta$ gene expression is a matter to consider in future studies.

The possibility of a dominant negative variant of the human PPAR $\delta$ adds to the complexity of PPAR $\delta$ as a transcriptional regulator. The alternative polyadenylation signal and premature stop-codon in human PPAR $\delta$ intron 8 are not conserved in mouse, indicating that this isoform is 
human-specific, similar to the dominant negative variants of PPAR $\alpha$ and PPAR $[45,46]$. Suggested orthologs of the human PPAR $\delta 2$ in chimpanzee and macaque, on the other hand, indicate that this could be a primate-specific isoform. Investigation of 5'-UTRs among human PPAR 22 transcripts shows that this isoform, similar to full-length PPAR $\delta$, is preferentially transcribed from a promoter upstream of exon 1 . Since the variability among 5 '-UTRs of PPAR $\delta 2$ is less pronounced, this isoform appears to be less subjected to alternative splicing and thus translational regulation.

Transcripts of PPAR $\delta 2$ were identified in placenta and adipose tissue. The occurrence and functional implications of PPAR 2 transcripts translated into protein in different cells and tissues, however, remains to be elucidated. Here we have shown for the first time in vitro that the isoform PPAR 82 represses the trans-activating ability of full-length PPAR $\delta$. The mode of action of dominant negative nuclear receptors in general is either competition for binding of DNA, auxiliary factors and cofactors or an effect on subcellular localization. A dominant negative mutant of the full-length mouse orthologous of PPAR $\delta$ (E114P) has been tested in a similar setting with a PPRE reporter gene construct and GW501516, and shown to dose-dependently inhibit PPAR $\delta$ induced luciferase activity. Contrary to PPAR $\delta 2$ this full-length mutant is suggested to bind ligand and PPRE but remains in a repressive form and acts by competing with wild type PPAR $\delta$ for binding to DNA $[47,48]$. The result of the mobility shift assay presented here indicates that PPAR $\delta 2$ exerts its inhibitory properties by another mechanism than competition for binding to PPREs.

\section{Conclusion}

The main finding of this study is the demonstration of multiple 5'-UTR splice variants of PPAR $\delta$ mRNA that can influence the translation capacity. Moreover, the alternative splicing of human PPAR $\delta$ is also reflected by the generation of a dominant negative isoform. Considering that PPAR $\delta$ is widely expressed, a master regulator of gene transcription and acts as a metabolic sensor, proper understanding of the factors affecting the expression level and activity of this nuclear receptor is of crucial importance. Dysregulation of alternative splicing might promote human disease [49]. In the case of human PPAR $\delta$, this would entail dysregulation of protein expression with effects on both the trans-activating and repressor potentials of PPAR $\delta$.

\section{Methods}

Oligonucleotides and TaqMan probes

Oligonucleotides used in this paper were purchased from Proligo (France) and Thermo Hybaid (Germany). The sequences of RACE and PCR primers are listed in Table 5 and TaqMan primers and probes are listed in Table 3.

\section{Rapid amplification of CDNA ends (RACE)}

Marathon-Ready cDNAs (Clontech) from human placenta, pancreas and adipose tissue were utilized for RACE studies according to the manufacturer's instructions. Two sequential rounds of 5'-RACE were carried out with the reverse gene-specific primer (GSP) Ex7Rev, followed by Ex6Rev or Ex3Rev in combination with adapter primers (AP1 and AP-2; Clontech). Purified fragments were sequenced using Big Dye Terminator Kit and an automatic sequencer (Genetic Analyzer 3100, Applied Biosystems). Nested PCR was subsequently performed using primers Ex5Rev, Ex4:1Rev, Ex2a:1Rev, Ex2a:2Rev, Ex2cRev and Ex2eRev combined with the adapter primer AP2. Sequencing was performed either directly on the PCR products or on samples of gel-purified fragments when multiple bands were obtained.

Another round of 5'-RACE was conducted on MarathonReady cDNAs using either a full-length PPAR $\delta$ (PPAR $\delta 1$ ) primer (Ex9:1Rev) or a PPAR 82 specific primer (In8:1Rev) in combination with the adapter primer AP1. Further rounds of PCR on these 5'-RACE products, thus enriched in either PPAR $\delta 1$ or PPAR 82 , were performed using exon/ exon specific primer pairs specified in the Result section (Figure 5).

Two sequential rounds of 3'-RACE were carried out using Marathon-Ready cDNAs and the gene-specific forward primers Ex8:1Fw and In8Fw in combination with adapter primers AP1 and AP-2, respectively. Sequencing was performed on PCR products as described above.

\section{RNA extraction, reverse transcription, PCR and real-time $P C R$ analysis}

Total RNA was extracted using RNeasy system (Qiagen) from a panel of human cell lines; the human hepatocellular carcinoma cell lines HepG2 and Huh7, the cervical epithelioid carcinoma cell line HeLa, the human acute monocytic leukaemia cell line THP-1 and kidney epithelial carcinoma cell line A498. One microgram of total RNA was reverse transcribed with a poly-dT primer using Superscript II (Invitrogen) according to the manufacturer's instructions. First strand cDNAs were subjected to PCR using exon specific primer pair combinations (Table 5 ). The PCR cycles were as follows: $94^{\circ} \mathrm{C}$ for $3 \mathrm{~min}$ followed by 36 cycles of $94^{\circ} \mathrm{C}$ for $20 \mathrm{sec}, 55^{\circ} \mathrm{C}$ for $30 \mathrm{sec}$, $72^{\circ} \mathrm{C}$ for $30 \mathrm{sec}$, and finally $72^{\circ} \mathrm{C}$ for $10 \mathrm{~min}$. Sequencing was performed on PCR products as described above. Realtime PCR (TaqMan analysis) was performed on cDNA from human cell lines and tissues according to the manufacturer's instructions (Applied Biosystem, USA) and the reaction conditions involved denaturation for $10 \mathrm{~min}$ at 
Table 5: Oligonucleotide primers used for RACE and PCR in this study

\begin{tabular}{|c|c|c|}
\hline Name & Target & Sequence (5'-3') \\
\hline \multicolumn{3}{|l|}{ Forward primers } \\
\hline ExI:IFw & exon 1 & 5'-TTAAGCTTGGTACCCGCGGACCTGGGGATTAATGG \\
\hline $\mathrm{Exl}: 2 \mathrm{Fw}$ & exon 1 & 5'-AATTCTGCGGAGCCTGCGG \\
\hline Ex2Fw & exon 2 & 5'-ACGTGATACTCACACAGTGG \\
\hline Ex2a:IFw & exon $2 a$ & 5'-GGAGCTCCAGGGAATACAATGTTCA \\
\hline Ex2a:2Fw & exon $2 a$ & 5'-CAGGCCCAGTGGCAGCAAT \\
\hline Ex2cFw & exon $2 c$ & 5'-GGCACTTGATGCTGTTGAATGGAG \\
\hline Ex2eFw & exon $2 \mathrm{e}$ & 5'-CCAGCTCTCCTTGACCTTGAACCTT \\
\hline Ex3Fw & exon 3 & 5'-AACTGAAGCCCGTGGAGCA \\
\hline Ex4Fw & exon 4 & 5'-GACCACAGCATGCACTTCCT \\
\hline Ex8:IFw & exon 8 & 5'-AGTGGCTTTGTCACCCGTGAGTTCCTG \\
\hline Ex8:2Fw & exon 8 & 5'-TCCGCAAACCCTTCAGTGATA \\
\hline $\ln 8 \mathrm{Fw}$ & intron $8 *$ & 5'-GGCTGAGCCAGGAGAATCGCTTGA \\
\hline \multicolumn{3}{|l|}{ Reverse primers } \\
\hline Ex2Rev & exon 2 & 5'-CTCGTTGGTGCATCTGTCTTCA \\
\hline Ex2a:IRev & exon $2 \mathrm{a}$ & 5'-CGCTCAGGAGGTACTTTGACCTCTTCC \\
\hline Ex2a:2Rev & exon $2 a$ & 5'-GCTCAGGGATGAACTGGACAACTGAC \\
\hline Ex2cRev & exon $2 c$ & 5'-ATGCTTCTGCTCAGAACCCAGCTCTCA \\
\hline Ex2eRev & exon $2 \mathrm{e}$ & 5'-AAGAGTGAAGGGCAGCTGAGTCCTGA \\
\hline Ex3Rev & exon 3 & 5'-GAAGCAGTCCTGTAGAGATCAT \\
\hline Ex4:IRev & exon 4 & 5'-CCCAGTCATAGCTCTGGCATCGTCT \\
\hline Ex4:2Rev & exon 4 & 5'-TGGCTGCTCCATGGCTGATCT \\
\hline Ex5Rev & exon 5 & 5'-GTCACAGCCCATCTGCAGTT \\
\hline Ex6Rev & exon 6 & 5'-CACTTCTCGTACTCCAGCTTC \\
\hline Ex7Rev & exon 7 & 5'-TGCCACCAGCTTCСТCTTC \\
\hline Ex8Rev & exon 8 & 5'-CCAGCCССTTCTCTGCCT \\
\hline Ex9:IRev & exon 9 & 5'-CTGGAGCAGAGGGTGCAGCGAGGTCT \\
\hline Ex9:2Rev & exon 9 & 5'-ATGGCATGCCCAGCTGTGC \\
\hline $\ln 8: \mid \operatorname{Rev}$ & intron $8^{*}$ & 5'-GATTACAGGTGTGAGCCACCACGTCTG \\
\hline In8:2Rev & intron $8^{*}$ & 5'-CCCACATTAACATGACAGCAT \\
\hline
\end{tabular}

The primers are annotated according to the target exon or intron in the human PPAR $\delta$ gene.

* Comparable to the 3 '-UTR of PPAR $\delta 2$

$95^{\circ} \mathrm{C}$, and 45 cycles of amplification with $15 \mathrm{sec}$ at $95^{\circ} \mathrm{C}$ and $1 \mathrm{~min}$ at $60^{\circ} \mathrm{C}$. Primers and probes are listed in Table 3. Two different cDNAs obtained using total RNA from each cell line (described above) or tissue (Clontech) were analysed twice and determined in triplicates using an ABI prism 7000 (Applied Biosystem). Standard curves were run for all assays to ensure consistent amplification efficacy. All variants were normalised to the Ex8:9 assay using the comparative $\mathrm{C}_{\mathrm{T}}$-method (User Bulletin \#2, December 11, 1997 (updated 10/2001); ABI PRISM 7700 Sequence Detection System) and presented as relative expression levels.

\section{Reporter gene constructs, transient transfections and luciferase assays}

A luciferase reporter gene construct covering the proximal promoter region of the human PPAR $\delta$ gene upstream of exon 1, from -733 to +44 cloned into pGL3 Basic (Promega) (hereafter referred to as the $-733 \mathrm{bp}$ construct) has previously been described [50]. Additional constructs covering longer (2.6 kb and $1.5 \mathrm{~kb}$ ) and shorter sequences (171 bp, $61 \mathrm{bp}$ and $48 \mathrm{bp}$ ) of this promoter were created from restriction enzyme digests of a genomic PPAR $\delta$ clone [25] and the -733 bp construct. Likewise, genomic upstream sequences (approximately $1 \mathrm{~kb}$ and $250 \mathrm{bp}$ ) for each of the four alternative transcription start sites identified in this study were PCR amplified and cloned into pGL3 Basic.

The Huh7 and HeLa cell lines were maintained in Dulbecco's modified Eagle's medium (D-MEM $1 \mathrm{~g} / \mathrm{ml}$ glucose, Invitrogen) supplemented with $10 \%$ fetal bovine serum, penicillin $(100 \mathrm{units} / \mathrm{ml})$ and streptomycin $(100 \mathrm{ug} / \mathrm{ml})$ at $37^{\circ} \mathrm{C}$ in $5 \% \mathrm{CO}_{2}$ in air. Approximately $1 \times 10^{5}$ cells/well were plated on a 24 -well plate and transiently transfected after $24 \mathrm{~h}$ with $100 \mathrm{ng}$ of the reporter gene constructs or empty vector using Lipofectamin (Invitrogen) according to the manufacturer's protocol. Plasmid pSV- $\beta$-galactosidase control vector (Promega) (260 ng) was co-transfected for normalization of the transfection efficiency. After $24 \mathrm{~h}$, cells were washed, lysed and luciferase activity was measured as previously described [51]. The $\beta$-galactosidase enzyme assay system (Promega) was used for measuring the $\beta$-galactosidase activity in cell lysates 
according to the manufacturer's instructions. The activities were determined in quadruplicates and the data presented are based on the mean $( \pm \mathrm{SD})$ luciferase $/ \beta$ galactosidase ratios of three independent transfections, setting the value of empty vector to 1 .

\section{Coupled transcription/translation}

A fragment covering the full-length PPAR $\delta$ mRNA sequence from exon 1 to the 3'-UTR was amplified using Marathon placenta cDNA and primers Ex1:1Fw (introducing a KpnI restriction site in the 5'-end) and Ex9:2Rev. The fragment was cloned into the pTNT vector (Promega) using the restriction sites $\mathrm{KpnI}$ and $\mathrm{SmaI}$ in the vector and KpnI and MscI in PPARS, respectively. Variable 5'-UTRs upstream of exon 4 were introduced using the primerbased KpnI site in the 5 '-end of exon 1 and an NcoI site in exon 4. The 5'-UTR sequences were amplified using Marathon cDNAs and combinations of exon specific primers Ex1:1Fw, Ex2a:1Fw, Ex2a:2Fw, Ex2eFw, Ex2eRev, Ex3Rev and Ex4:2Rev. Longer 5'-UTRs were amplified in two pieces, subcloned in PGEM-T vector (Promega) and ligated together prior to being introduced in the 5 -end of PPAR $\delta$ in PTNT vector. Coupled in vitro transcription and translation was performed on these plamids using a TNT Quick Coupled Transcription/Translation System (Promega) and [35S]methionine (Amersham) according to the manufacturer's instructions. The $\left[{ }^{35} \mathrm{~S}\right]$ methionine labelled products were separated by $10 \%$ SDS-polyacrylamide gel electrophoresis (SDS-PAGE), subjected to autoradiography and analysed on a Phosphorlmager scanner (Fuji film Bas-2500, Australia). The in vitro translated products were also subjected to Western blot analysis under reducing conditions on $10 \%$ SDS-PAGE as described by Laemmli [52] using the polyclonal PPAR $\delta$ specific antibody IMG-3297 (Nordic Biosite, Sweden) and a horseradish peroxidase-labelled secondary antibody. Detection was performed with the ECL Advanced Western blot detection system (Amersham). Both the autoradiographic and Western blot bands were quantified using the NIH ImageJ software [53]. The amounts of plasmids used $(1 \mu \mathrm{g})$ were within a range of saturating conditions where the outcome of the transcription/translation reactions was independent on the differences in target DNA concentration introduced by the different lengths of the 5'-UTRs.

\section{Expression vectors for PPAR $\delta$, transient transfections and Luciferase assays}

The expression vector for full-length PPAR $\delta$ (PPAR $\delta 1$ ) under the control of the human cytomegalovirus (CMV) promoter was a kind gift of Dr CN Palmer and is described elsewhere [54]. The expression vector for PPAR $\delta 2$ was created using an EcoRV site in the coding region, common to both PPAR $\delta 1$ and 2, and replacing the downstream sequence of the expression vector with the corresponding 3 '-sequence of PPAR $\delta 2$. The 3'-sequence of PPAR $\delta 2$ was obtained by PCR using a genomic clone of PPAR $\delta$ as template [25], and the forward primer Ex8:2Fw and reverse primer In8:2Rev. The reporter construct pFABPLUC containing four copies of the PPRE from the human liver FABP gene in front of the HSV-TK promoter is described elsewhere [54]. Growth and transfection of HeLa cells, Luciferase assay, and $\beta$-galactosidase assay were performed as described above. Nuclear extract prepared as previously described [55] from HeLa cells transfected with the expression vectors for PPAR $\delta 1$ and PPAR $\delta 2$, respectively, was subjected to Western blot analysis as described above, using the PPAR $\delta$ antibody sc-7197 (Santa Cruz Biotechnology). Nuclear extract prepared from untransfected HeLa cells was used as a negative control.

\section{Electrophoretic mobility shift assay, EMSA}

The binding properties of PPAR $\delta 1$ and PPAR $\delta 2$, respectively, to the functional PPRE of the rat acyl-CoA oxidase gene with and without the heterodimer partner RXR were investigated by EMSA. Human PPAR $\delta 1$ and PPAR $\delta 2$, cloned into the TNT vector, and TNT-hRXR $\alpha$ (a kind gift from Dr Glinghammar, AZ, Sweden) were in vitro transcribed/translated using the rabbit reticulocyte lysate system (Promega) as previously described but with unlabelled methionine. Incubation for EMSA was conducted as previously described [56] using $6 \mu \mathrm{l}$ of in vitro produced PPAR $\delta 1$ or PPAR $\delta 2$ with $2 \mu \mathrm{l}$ of RXR $\alpha$ or mock lysate produced using an empty vector, in a total volume of $20 \mu \mathrm{l}(2 \mu \mathrm{g}$ poly(dI-dC), $0.75 \mathrm{mM}$ EDTA pH 8.0, 18 $\mathrm{mM}$ HEPES pH 7.9, $0.5 \mathrm{mM}$ dithiothreitol, 4\% Ficoll), and $[\gamma-32 \mathrm{P}]$-end labelled double stranded ACO-oligo (5'ggaccAGGACAaAGGTCAcgttcgg-3')[57]. For competition, a 100-fold molar excess of unlabelled double stranded ACO-oligo was added. A PPAR $\delta$ antibody sc-7197 was used for supershift. This antibody, directed against the Nterminal region (epitope 2-75) of human PPAR $\delta$, was shown to detect both variants of in vitro translated PPAR $\delta$ using Western blot (data not shown). DNA-protein complexes were applied to a $6 \%$ polyacrylamide gel and run for 4 hours at $200 \mathrm{~V}$ in $0.25 \times \mathrm{TBE}$ at $4{ }^{\circ} \mathrm{C}$. The gel was dried, subjected to autoradiography and analysed on a PhosphoImager scanner.

\section{Bioinformatics and comparative genomics}

The NCBI human Genome Browser, the human ESTsearch tool and homologue RefSeq of PPAR $\delta$ were provided by NCBI [58]. The Evolutionary Conserved Regions Browser tool (ECR Browser) [59] was used to identify sequence conservation between species, ClustalW [60] for sequence alignments and sequence identity scores and the RepeatMasker [61] to unravel repetitive elements in PPAR $\delta$ genes. Localization and extraction of relevant sequences for comparative analysis between species was performed using the ECR Browser tool and defined regions were subsequently extracted from the PPAR $\delta$ gene 
RefSeq for each species and aligned to the relevant human exon sequences using ClustalW.

\section{Abbreviations}

PPAR, peroxisome proliferator-activated receptor; PPRE, peroxisome proliferator response element; RACE, rapid amplification of cDNA ends; GSP, gene specific primer; UTR, untranslated region; RT, reverse transcription; PCR, polymerase chain reaction; SDS, sodium dodecyl sulfate; bp, base pair(s); ORF, open reading frame; uORF, upstream open reading frame; EST, expressed sequence tags; RefSeq, reference sequence

\section{Authors' contributions}

KL performed all RACE, RT-PCR analysis, reporter gene assays, bioinformatics and comparative genomics including analysis and interpretations and drafted the manuscript. PT performed all in vitro coupled transcription/ translation, Western Blot, EMSA and Real-time PCR experiments including data analysis and interpretations and coauthored the manuscript. EE coordinated the study and co-authored the manuscript and was responsible together with KL for the study design. AH co-authored the manuscript and was involved in project development. All contributing authors reviewed and approved the final copy of this manuscript.

\section{Acknowledgements}

We thank Dr Tobias Cassel for his help in producing reporter gene constructs used in this study. This study was supported by the Swedish Medical Research Council ( I 2659) (EE and KL), the Swedish Heart-Lung Foundation (EE and $\mathrm{AH}$ ), the Swedish Diabetes Foundation (EE and $K L)$, Professor Nanna Svartz Foundation (EE), Magn. Bergvalls Foundation (KL), the Foundation for Old Servants (EE), the Stockholm County Council (AH), and the Karolinska Institutet (EE).

\section{References}

I. van Bilsen $M$, van der Vusse $G$ J, Gilde $A$ J, Lindhout $M$, van der Lee KA Peroxisome proliferator-activated receptors: lipid binding proteins controling gene expression. Mol Cell Biochem 2002, 239(I-2): $|3|-\mid 38$.

2. Hihi AK, Michalik L, Wahli W: PPARs: transcriptional effectors of fatty acids and their derivatives. Cell Mol Life Sci 2002 59(5):790-798.

3. Kota BP, Huang TH, Roufogalis BD: An overview on biological mechanisms of PPARs. Pharmacol Res 2005, 5 I (2):85-94.

4. Desvergne B, Wahli W: Peroxisome proliferator-activated receptors: nuclear control of metabolism. Endocr Rev 1999 , 20(5):649-688.

5. Ferre $\mathrm{P}$ : The biology of peroxisome proliferator-activated receptors: relationship with lipid metabolism and insulin sensitivity. Diabetes 2004, 53(Suppl I):S43-50.

6. Xu HE, Lambert MH, Montana VG, Plunket KD, Moore LB, Collins JL, Oplinger JA, Kliewer SA, Gampe RT Jr, McKee DD, Moore JT, Willson TM: Structural determinants of ligand binding selectivity between the peroxisome proliferator-activated receptors. Proc Natl Acad Sci USA 200I, 98(24):13919-13924.

7. Forman BM, Chen J, Evans RM: Hypolipidemic drugs, polyunsaturated fatty acids, and eicosanoids are ligands for peroxisome proliferator-activated receptors alpha and delta. Proc Natl Acad Sci USA 1997, 94(9):43 I 2-43 I7.

8. Xu HE, Lambert MH, Montana VG, Parks DJ, Blanchard SG, Brown PJ Sternbach DD, Lehmann JM, Wisely GB, Willson TM, Kliewer SA, Mil- burn MV: Molecular recognition of fatty acids by peroxisome proliferator-activated receptors. Mol Cell I999, 3(3):397-403.

9. Shi Y, Hon M, Evans RM: The peroxisome proliferator-activated receptor delta, an integrator of transcriptional repression and nuclear receptor signaling. Proc Natl Acad Sci USA 2002, 99(5):2613-2618.

10. Jow L, Mukherjee R: The human peroxisome proliferator-activated receptor (PPAR) subtype NUCI represses the activation of hPPAR alpha and thyroid hormone receptors. J Biol Chem 1995, 270(8):3836-3840.

II. Krogsdam AM, Nielsen CA, Neve S, Holst D, Helledie T, Thomsen B, Bendixen C, Mandrup S, Kristiansen K: Nuclear receptor corepressor-dependent repression of peroxisome-proliferatoractivated receptor delta-mediated transactivation. Biochem 2002, 363(Pt I): I57-165.

12. Muoio DM, MacLean PS, Lang DB, Li S, Houmard JA, Way JM, Winegar DA, Corton JC, Dohm GL, Kraus WE: Fatty acid homeostasis and induction of lipid regulatory genes in skeletal muscles of peroxisome proliferator-activated receptor (PPAR) alpha knock-out mice. Evidence for compensatory regulation by PPAR delta. J Biol Chem 2002, 277(29):26089-26097.

13. Barish GD, Narkar VA, Evans RM: PPAR delta: a dagger in the heart of the metabolic syndrome. I Clin Invest 2006, I I 6(3):590-597.

14. Peters JM, Lee SS, Li W, Ward JM, Gavrilova O, Everett C, Reitman ML, Hudson LD, Gonzalez F]: Growth, adipose, brain, and skin alterations resulting from targeted disruption of the mouse peroxisome proliferator-activated receptor beta(delta). Mo Cell Biol 2000, 20(14):5। 19-5I28.

15. Barak Y, Liao D, He W, Ong ES, Nelson MC, Olefsky JM, Boland R, Evans RM: Effects of peroxisome proliferator-activated receptor delta on placentation, adiposity, and colorectal cancer. Proc Natl Acad Sci USA 2002, 99(I):303-308

16. Oliver WR Jr, Shenk JL, Snaith MR, Russell CS, Plunket KD, Bodkin NL, Lewis MC, Winegar DA, Sznaidman ML, Lambert MH, Xu HE, Sternbach DD, Kliewer SA, Hansen BC, Willson TM: A selective peroxisome proliferator-activated receptor delta agonist promotes reverse cholesterol transport. Proc Natl Acad Sci USA 2001, 98(9):5306-531I.

17. Dressel U, Allen TL, Pippal JB, Rohde PR, Lau P, Muscat GE: The peroxisome proliferator-activated receptor beta/delta agonist, GW50 regulates the expression of genes involved in lipid catabolism and energy uncoupling in skeletal muscle cells. Mol Endocrinol I5 16, I 7(12):2477-2493.

18. Wang YX, Zhang CL, Yu RT, Cho HK, Nelson MC, Bayuga-Ocampo CR, Ham J, Kang H, Evans RM: Regulation of muscle fiber type and running endurance by PPARdelta. PLoS Biol 2004, 2(I 0):e294.

19. Luquet S, Lopez-Soriano J, Holst D, Fredenrich A, Melki J, Rassoulzadegan M, Grimaldi PA: Peroxisome proliferator-activated receptor delta controls muscle development and oxidative capability. Faseb J 2003, I 7( I 5):2299-230I.

20. Al-Khalili L, Chibalin AV, Kannisto K, Zhang BB, Permert J, Holman GD, Ehrenborg E, Ding VD, Zierath JR, Krook A: Insulin action in cultured human skeletal muscle cells during differentiation: assessment of cell surface GLUT4 and GLUTI content. Cell Mol Life Sci 2003, 60(5):991-998.

21. Kramer DK, Al-Khalili L, Perrini S, Skogsberg J, Wretenberg P, Kannisto $\mathrm{K}$, Wallberg-Henriksson $\mathrm{H}$, Ehrenborg $\mathrm{E}$, Zierath JR, Krook $\mathrm{A}$ : Direct activation of glucose transport in primary human myotubes after activation of peroxisome proliferator-activated receptor delta. Diabetes 2005, 54(4): I I 57- I I63.

22. Chevillotte E, Rieusset J, Roques M, Desage M, Vidal H: The regulation of uncoupling protein-2 gene expression by omega-6 polyunsaturated fatty acids in human skeletal muscle cells involves multiple pathways, including the nuclear receptor peroxisome proliferator-activated receptor beta. I Biol Chem 200I, 276(14): I0853-10860.

23. Holst D, Luquet S, Nogueira V, Kristiansen K, Leverve X, Grimaldi $P A$ : Nutritional regulation and role of peroxisome proliferator-activated receptor delta in fatty acid catabolism in skeletal muscle. Biochim Biophys Acta 2003, I 633(I):43-50.

24. Tanaka T, Yamamoto J, Iwasaki S, Asaba H, Hamura H, lkeda $Y$, Watanabe M, Magoori K, loka RX, Tachibana K, Watanabey Y, Uchiyama $Y$, Sumi K, Iguchi $H$, Ito $S$, Doi T: Activation of peroxisome proliferator-activated receptor delta induces fatty acid beta- 
oxidation in skeletal muscle and attenuates metabolic syndrome. Proc Natl Acad Sci USA 2003, 100:15924-15929.

25. Skogsberg J, Kannisto K, Roshani L, Gagne E, Hamsten A, Larsson C, Ehrenborg E: Characterization of the human peroxisome proliferator activated receptor delta gene and its expression. Int J Mol Med 2000, 6(I):73-8I.

26. Pelton P: GW-50 I 516 GlaxoSmithKline/Ligand. Curr Opin Investig Drugs 2006, 7(4):360-370.

27. Larsen LK, Amri EZ, Mandrup S, Pacot C, Kristiansen K: Genomic organization of the mouse peroxisome proliferator-activated receptor beta/delta gene: alternative promoter usage and splicing yield transcripts exhibiting differential translational efficiency. Biochem J 2002, 366(Pt 3):767-775.

28. Ovcharenko I, Nobrega MA, Loots GG, Stubbs L: ECR Browser: a tool for visualizing and accessing data from comparisons of multiple vertebrate genomes. Nucleic Acids Res 2004, 32:W280-286.

29. Batzer MA, Deininger PL: Alu repeats and human genomic diversity. Nat Rev Genet 2002, 3(5):370-379.

30. Zhang $\mathrm{XH}$, Chasin LA: Comparison of multiple vertebrate genomes reveals the birth and evolution of human exons. Proc Natl Acad Sci USA 2006, 103(36): 13427-13432.

31. Sorek R, Lev-Maor G, Reznik M, Dagan T, Belinky F, Graur D, Ast G: Minimal conditions for exonization of intronic sequences: 5 splice site formation in alu exons. Mol Cell 2004, I 4(2):22I-23I

32. Lev-Maor G, Sorek R, Shomron N, Ast G: The birth of an alternatively spliced exon: 3' splice-site selection in Alu exons. Science 2003, 300(5623): |288-|29|.

33. Wang H, Xing J, Grover D, Hedges DJ, Han K, Walker JA, Batzer MA SVA elements: a hominid-specific retroposon family. J Mol Biol 2005, 354(4):994-1007.

34. Lazennec G, Canaple L, Saugy D, Wahli W: Activation of peroxisome proliferator-activated receptors (PPARs) by their ligands and protein kinase A activators. Mol Endocrinol 2000, I 4(I2): I 962-1975.

35. Diradourian C, Girard J, Pegorier JP: Phosphorylation of PPARs: from molecular characterization to physiological relevance. Biochimie 2005, 87(I):33-38.

36. Hansen JB, Zhang H, Rasmussen TH, Petersen RK, Flindt EN, Kristiansen K: Peroxisome proliferator-activated receptor delta (PPARdelta)-mediated regulation of preadipocyte proliferation and gene expression is dependent on cAMP signaling. Biol Chem 200I, 276(5):3I75-3I82.

37. Blanquart C, Barbier O, Fruchart JC, Staels B, Glineur C: Peroxisome proliferator-activated receptors: regulation of transcriptional activities and roles in inflammation. I Steroid Biochem Mol Biol 2003, 85(2-5):267-273.

38. Gelman L, Michalik L, Desvergne B, Wahli W: Kinase signaling cascades that modulate peroxisome proliferator-activated receptors. Curr Opin Cell Biol 2005, I7(2):216-222.

39. Chen $Y$, Jimenez AR, Medh JD: Identification and regulation of novel PPAR-gamma splice variants in human THP-I macrophages. Biochim Biophys Acta 2006, I759(I-2):32-43.

40. Kozak M: Initiation of translation in prokaryotes and eukaryotes. Gene 1999, 234(2): 187-208.

4I. lacono M. Mignone F. Pesole G: UAUG and uORFs in human and rodent 5'untranslated mRNAs. Gene 2005, 349:97-105.

42. Wang $X Q$, Rothnagel JA: 5 '-untranslated regions with multiple upstream AUG codons can support low-level translation via leaky scanning and reinitiation. Nucleic Acids Res 2004, 32(4): 1382-139|.

43. van der Velden AW, Thomas AA: The role of the 5 ' untranslated region of an mRNA in translation regulation during development. Int J Biochem Cell Biol I999, 3 I (I):87-I06.

44. Wang $W$, Zheng $H$, Yang S, Yu H, Li J, Jiang H, Su J, Yang L, Zhang J McDermott J, Samudrala R, Wang J, Yang H, Yu J, Kristiansen K, Wong GK: Origin and evolution of new exons in rodents. Genome Res 2005, I 5(9): I 258-1264.

45. Gervois P, Torra IP, Chinetti G, Grotzinger T, Dubois G, Fruchart JC, Fruchart-Najib J, Leitersdorf E, Staels B: A truncated human peroxisome proliferator-activated receptor alpha splice variant with dominant negative activity. Mol Endocrinol 1999 , 13(9): 1535-1549.

46. Sabatino L, Casamassimi A, Peluso G, Barone MV, Capaccio D, Migliore C, Bonelli P, Pedicini A, Febbraro A, Ciccodicola A, Colantuoni $\checkmark$ : A novel peroxisome proliferator-activated receptor gamma isoform with dominant negative activity generated by alternative splicing. J Biol Chem 2005, 280(28):265I7-26525.

47. Bastie C, Luquet S, Holst D, Jehl-Pietri C, Grimaldi PA: Alterations of peroxisome proliferator-activated receptor delta activity affect fatty acid-controlled adipose differentiation. J Biol Chem 2000, 275(49):38768-38773.

48. Pesant M, Sueur S, Dutartre P, Tallandier M, Grimaldi PA, Rochette L, Connat JL: Peroxisome proliferator-activated receptor delta (PPARdelta) activation protects $\mathrm{H} 9 \mathrm{c} 2$ cardiomyoblasts from oxidative stress-induced apoptosis. Cardiovasc Res 2006, 69(2):440-449

49. Caceres JF, Kornblihtt AR: Alternative splicing: multiple control mechanisms and involvement in human disease. Trends Genet 2002, 18(4): $186-193$.

50. Skogsberg J, Kannisto K, Cassel TN, Hamsten A, Eriksson P, Ehrenborg $\mathrm{E}$ : Evidence that peroxisome proliferator-activated receptor delta influences cholesterol metabolism in men. Arterioscler Thromb Vasc Biol 2003, 23(4):637-643.

5I. Glinghammar B, Skogsberg J, Hamsten A, Ehrenborg E: PPARdelta activation induces COX-2 gene expression and cell proliferation in human hepatocellular carcinoma cells. Biochem Biophys Res Commun 2003, 308(2):36I-368.

52. Laemmli U: Cleavage of structural proteins during the assembly of the head of bacteriophage T4. Nature 1970, 227:660-685.

53. Research Services Branch [http://rsb.info.nih.gov]

54. Vosper H, Patel L, Graham TL, Khoudoli GA, Hill A, Macphee CH, Pinto I, Smith SA, Suckling KE, Wolf CR, Palmer CN: The peroxisome proliferator-activated receptor delta promotes lipid accumulation in human macrophages. I Biol Chem 200I, 276(47):44258-44265.

55. Andrews NC, Faller DV: A rapid micropreparation technique for extraction of DNA-binding proteins from limiting numbers of mammalian cells. Nucleic Acids Res 199I, 19(9):2499.

56. Dawson SJ, Wiman B, Hamsten A, Green F, Humphries S, Henney AM: The two allele sequences of a common polymorphism in the promoter of the plasminogen activator inhibitor-I (PAII) gene respond differently to interleukin-I in HepG2 cells. Biol Chem 1993, 268(15):10739-10745.

57. Juge-Aubry C, Pernin A, Favez T, Burger AG, Wahli W, Meier CA Desvergne B: DNA binding properties of peroxisome proliferator-activated receptor subtypes on various natural peroxisome proliferator response elements. Importance of the 5'flanking region. J Biol Chem 1997, 272(40):25252-25259.

58. National Center for Biotechnology Information [http:// www.ncbi.nlm.nih.gov]

59. ECR Browser [http://ecrbrowser.dcode.org]

60. ClustalW [http://www.ebi.ac.uk/clustalw]

61. RepeatMasker [http://www.repeatmasker.org] Publish with Biomed Central and every
scientist can read your work free of charge

"BioMed Central will be the most significant development for disseminating the results of biomedical research in our lifetime. "

Sir Paul Nurse, Cancer Research UK

Your research papers will be:

- available free of charge to the entire biomedical community

- peer reviewed and published immediately upon acceptance

- cited in PubMed and archived on PubMed Central

- yours - you keep the copyright
BioMedcentral 